\title{
Nocardiopsis nikkonensis sp. nov., isolated from a compost sample
}

Correspondence

Hideki Yamamura hyamamura@yamanashi.ac.jp

\author{
Hideki Yamamura, ${ }^{1}$ Shin-ya Ohkubo, ${ }^{1}$ Yuumi Ishida, ${ }^{2}$ Misa Otoguro, ${ }^{2}$ \\ Tomohiko Tamura $^{2}$ and Masayuki Hayakawa ${ }^{1}$
}

\author{
${ }^{1}$ Division of Applied Biological Sciences, Interdisciplinary Graduate School of Medicine and \\ Engineering, University of Yamanashi, Takeda-4, Kofu 400-8511, Japan \\ ${ }^{2}$ NITE Biological Resource Center, National Institute of Technology and Evaluation, Kazusakamatari \\ 2-5-8, Kisarazu, Chiba 292-0818, Japan
}

\begin{abstract}
An actinomycete strain, designated $\mathrm{YU} 1183-22^{\top}$, was isolated from a compost sample collected in Nikko, Japan. The isolate formed white aerial mycelium with relatively long aerial hyphae showing chains of arthrospores. Strain YU1183-22 ${ }^{\top}$ grew with 0-10\% (w/v) NaCl, at pH 6-11 and at $10-37{ }^{\circ} \mathrm{C}$ (optimum $30{ }^{\circ} \mathrm{C}$ ). Strain YU1183-22 ${ }^{\top}$ contained meso-diaminopimelic acid and no diagnostic sugars. The predominant menaquinones were $M K-10\left(\mathrm{H}_{10}\right)$ and $\mathrm{MK}-10\left(\mathrm{H}_{8}\right)$. The polar lipids were phosphatidylcholine and phosphatidylglycerol. The major cellular fatty acids were iso- $\mathrm{C}_{16: 0}$, anteiso- $\mathrm{C}_{17: 0}$ and tuberculostearic acid. The $\mathrm{G}+\mathrm{C}$ content of the DNA was $72.3 \mathrm{~mol} \%$. Chemotaxonomic and morphological characterization clearly demonstrated that strain YU1183-22 $2^{\top}$ belonged to the genus Nocardiopsis. Phylogenetic analysis using $16 \mathrm{~S}$ rRNA gene sequences showed that the isolate was closely related to Nocardiopsis salina YIM $90010^{\top}$ (98.0\% 16S rRNA gene sequence similarity), Nocardiopsis xinjiangensis YIM $90004^{\top}(97.9 \%)$ and Nocardiopsis kunsanensis $\mathrm{HA}-9^{\top}(97.3 \%)$. However, DNA-DNA relatedness as well as physiological and biochemical analyses showed that strain $\mathrm{YU} 1183-22^{\top}$ could be differentiated from its closest phylogenetic relatives. It is proposed that this strain be classified as a representative of a novel species of the genus Nocardiopsis, with the name Nocardiopsis nikkonensis sp. nov. The type strain is YU1183-22 ${ }^{\top}\left(=\operatorname{NBRC} 102170^{\top}=\right.$ KCTC $\left.19666^{\top}\right)$.
\end{abstract}

The genus Nocardiopsis is a member of the family Nocardiopsaceae (Meyer, 1976) and, at the time of writing, about 30 species have been described, including Nocardiopsis arabia, N. valliformis, N. quinghaiensis and N. ganjiahuensis (Hozzein \& Goodfellow, 2008; Yang et al., 2008; Chen et al., 2008; Zhang et al., 2008). Many members of the genus Nocardiopsis have been isolated from hypersaline or alkaline environments. However, others have been isolated from non-hypersaline environments, including the sputum of a kidney transplant patient, the rhizosphere of Casuarina sp. and the atmosphere of a composting facility (Yassin et al., 1997; Evtushenko et al., 2000; Kämpfer et al., 2002). Nocardiopsis species are of value to industry as they are known to produce bioactive agents such as griseusin D, apoptolidin and methylpendolmycin (Li et al., 2007; Kim et al., 1997; Sun et al., 1991). Hence, the discovery of additional species of this genus will

Abbreviation: ISP, International Streptomyces Project.

The GenBank/EMBL/DDBJ accession number for the 16S rRNA gene sequence of strain YU1183-22 ${ }^{\top}$ is AB491226.

A scanning electron micrograph of strain $Y \cup 1183-22^{\top}$ is available with the online version of this paper. contribute both to an understanding of their ecological roles and to the provision of bioresources for industrial applications.

Strain YU1183-22 $2^{\mathrm{T}}$ was isolated from a matured compost sample collected in Nikko, Japan, by growth on HV agar (Hayakawa \& Nonomura, 1987) containing $\left(1^{-1}\right) 20 \mathrm{mg}$ nalidixic acid, $50 \mathrm{mg}$ cycloheximide and $100 \mathrm{~g} \mathrm{NaCl}$. After incubation at $28{ }^{\circ} \mathrm{C}$ for 14 days, colonies of strain YU1183$22^{\mathrm{T}}$ showed a thin, flat morphology with sparse, white, aerial hyphae.

Morphological features of cells of strain YU1183-22 ${ }^{\mathrm{T}}$ grown on $\mathrm{HV}$ agar and oatmeal-YGG agar (Hayakawa et al., 1982) at $28{ }^{\circ} \mathrm{C}$ for 14 days were analysed by light and scanning electron microscopy. Cultural characteristics were determined after 2 weeks at $28{ }^{\circ} \mathrm{C}$ by using the methods adopted in the International Streptomyces Project (ISP) (Shirling \& Gottlieb, 1966). All media were supplemented with $3 \%(\mathrm{w} / \mathrm{v}) \mathrm{NaCl}$ and the colours of both substrate and aerial mycelia were determined according to Japan Colour Research Institute (1954). The detailed results are shown in Table 1. Spore motility in hanging drops was examined by light microscopy. Gram staining was examined by Hucker's 
method (Gerhardt, 1981). Carbon source utilization was examined using well-established procedures (Isik et al., 1999 ) with the addition of $3 \% \mathrm{NaCl}$. Nitrate reduction was determined after 7 and 14 days of growth by the addition of $0.2 \mathrm{ml}$ each of Griess-Ilosvay reagents I and II to stab cultures in sloppy nitrate medium supplemented with $0.2 \%$ $(\mathrm{w} / \mathrm{v}) \mathrm{KNO}_{3}$ and $0.6 \%$ Bacto agar (Difco) (Gordon \& Mihm, 1962). Lipolysis was assessed on Sierra's medium (Sierra, 1957) using Tween 80 as a substrate. Hydrogen sulfide formation was detected by insertion of sterile lead acetate filter paper strips into the necks of the culture tubes containing ISP 6 medium (Küster \& Williams, 1964). Melanin production was determined after 1-4 days of growth on ISP 6 and ISP 7 (Shirling \& Gottlieb, 1966). Conditions for growth were tested using modified CM + YE medium (JCM medium no. 275) as follows. Growth at 15, 20, 25, 30, 37, 42 and $45{ }^{\circ} \mathrm{C}$ and $\mathrm{pH} \mathrm{5,} \mathrm{6,} \mathrm{7,} \mathrm{8,} \mathrm{9,} 10$ and 11 was measured after 7 and 14 days; growth at $10{ }^{\circ} \mathrm{C}$ was also assayed after 6 weeks. Growth with $0-20 \%(w / v) ~ N a C l$ was determined after 14 and 21 days (Williams et al., 1983).

Diaminopimelic acid isomers and sugars in whole-cell hydrolysates were analysed based on the methods established by Hasegawa et al. (1983) and Schaal (1985), respectively. Standard procedures were used for extraction and analysis of fatty acids (Tamura et al., 1994) and isoprenoid quinones and polar lipids (Minnikin et al., 1984) and the results were compared with the appropriate controls. Chromosomal DNA from strain YU1183-22 ${ }^{\mathrm{T}}$ was isolated and purified by the method of Saito \& Miura (1963) with a minor modification (Hatano et al., 2003). The G $+C$ content of DNA from strain YU1183-22 ${ }^{\mathrm{T}}$ was determined by HPLC, as described by Tamura et al. (1994). DNA-DNA hybridization was carried out as described by Kusunoki et al. (1991) using biotinylated DNA.

PCR amplification of the 16S rRNA gene from strain YU1183-22 $2^{\mathrm{T}}$ was carried out according to the procedures described by Tamura \& Hatano (2001) and the amplification products were directly sequenced using an ABI Prism BigDye Terminator cycle sequencing kit (PE Applied Biosystems) and an automated DNA sequencer (model
3100 Genetic Analyzer; PE Applied Biosystems). The 16S rRNA gene sequence obtained was aligned with reference sequences of the genus Nocardiopsis available from public databases by using CLUSTAL x (Thompson et al., 1997). Phylogenetic trees were reconstructed by using MEGA version 4 (Tamura et al., 2007) and CLUSTAL x for the neighbour-joining method with $K_{\text {nuc }}$ values (Saitou \& Nei, 1987) and minimum-evolution and maximum-parsimony methods (Takahashi \& Nei, 2000) and PHYML (Guindon et al., 2005) for the maximum-likelihood method. The topologies of the trees were evaluated by bootstrap analysis (Felsenstein, 1985) based on 1000 resamplings (neighbourjoining, maximum-parsimony and minimum-evolution) and 500 resamplings (maximum-likelihood). 16S rRNA gene sequence similarity was calculated using the EzTaxon server (http://www.eztaxon.org/; Chun et al., 2007).

Chemotaxonomic and morphological characteristics of strain YU1183-22 ${ }^{\mathrm{T}}$ were consistent with its assignment to the genus Nocardiopsis ( $\mathrm{Li}$ et al., 2004; Hozzein \& Goodfellow, 2008). A whole-cell hydrolysate of strain YU1183-22 $2^{\mathrm{T}}$ contained meso-diaminopimelic acid and displayed no diagnostic sugars (wall chemotype III sensu Lechevalier \& Lechevalier, 1970). The major menaquinones were MK-10 $\left(\mathrm{H}_{8}\right)(28.1 \%)$ and MK-10 $\left(\mathrm{H}_{10}\right)(24.1 \%)$. The major polar lipids were phosphatidylcholine and phosphatidylglycerol (phospholipid type PIII sensu Lechevalier et al., 1977). The major cellular fatty acids were iso- $\mathrm{C}_{16: 0}(26.0 \%)$, anteiso- $\mathrm{C}_{17: 0}(16.4 \%)$ and 10-methyl $\mathrm{C}_{18: 0}(16.3 \%$; tuberculostearic acid). Strain YU1183-22 ${ }^{\mathrm{T}}$ formed branched substrate hyphae, which fragmented into rod-shaped elements, and relatively long aerial hyphae with chains of arthrospores (Supplementary Fig. S1, available in IJSEM Online).

The almost-complete 16S rRNA gene sequence (1488 nt) of strain YU1183-22 $2^{\mathrm{T}}$ was compared with sequences of members of the genus Nocardiopsis. The highest $16 \mathrm{~S}$ rRNA gene sequence similarity was observed with Nocardiopsis lucentensis DSM $44048^{\mathrm{T}}$ (98.2\%), N. salina YIM $90010^{\mathrm{T}}$ $(98.0 \%), N$. dassonvillei subsp. albirubida DSM $40465^{\mathrm{T}}$ (X97882) $(98.0 \%)$, N. xinjiangensis YIM $90004^{\mathrm{T}}$ (97.9\%), N. alba DSM $43377^{\mathrm{T}}(97.8 \%)$, N. halotolerans DSM $44410^{\mathrm{T}}$

Table 1. Cultural characteristics of strain YU1183- $22^{\top}$

All media were adjusted to $\mathrm{pH} 7.0$ and supplemented with $3 \%(\mathrm{w} / \mathrm{v}) \mathrm{NaCl}$. The isolate formed white aerial mycelium on yeast extract/malt extract agar.

\begin{tabular}{|lcc|}
\hline Medium & Growth & Substrate mycelium \\
\hline Yeast extract-malt extract agar (ISP 2) & Good & Pale yellow \\
Oatmeal agar (ISP 3) & Poor & White \\
Inorganic salts-starch agar (ISP 4) & Poor & White \\
Glycerol-asparagine agar (ISP 5) & Woderate & White \\
Peptone-yeast extract-iron agar (ISP 6) & Moderate & Pale yellow \\
Tyrosine agar (ISP 7) & Moderate & White \\
Trypticase soy agar & Abundant & Pale yellow \\
Mueller-Hinton agar & Good & Pale yellow \\
\hline
\end{tabular}


(97.8\%), N. synnemataformans IMMIB D-1215 $5^{\mathrm{T}}$ (97.7\%), N. dassonvillei subsp. dassonvillei DSM $43111^{\mathrm{T}}(97.7 \%), N$. aegyptia DSM $44442^{\mathrm{T}}(97.5 \%)$ and N. kunsanensis HA-9 ${ }^{\mathrm{T}}$ $(97.3 \%)$. Neighbour-joining phylogenetic analysis revealed that strain YU1183-22 $2^{\mathrm{T}}$ formed a monophyletic clade with $N$. salina YIM $90010^{\mathrm{T}}, N$. kunsanensis $\mathrm{HA}-9^{\mathrm{T}}$ and $N$. xinjiangensis YIM $90004^{\mathrm{T}}$ and this cluster was also recovered with the other algorithms tested (Fig. 1). N. lucentensis DSM $44048^{\mathrm{T}}$ did not cluster with strain YU1183-22 ${ }^{\mathrm{T}}$.

DNA-DNA relatedness between strain YU1183-22 ${ }^{\mathrm{T}}$ and $N$. lucentensis NBRC $15854^{\mathrm{T}}$ and its closest phylogenetic neighbours was $45.7-52.9 \%$ (N. lucentensis, $51.7 \%$; $N$. salina JCM $13364^{\mathrm{T}}, 45.7 \%$; N. kunsanensis NBRC $100348^{\mathrm{T}}$, $52.9 \%$; and N. xinjiangensis NBRC $104162^{\mathrm{T}}, 48.7 \%$ ). These values were well below the $70 \%$ cut-off point recommended for the assignment of bacterial strains to the same genomic species (Wayne et al., 1987).

Strain YU1183-22 ${ }^{\mathrm{T}}$ could also be distinguished from its phylogenetic neighbours by a range of biochemical and phenotypic characteristics (Table 2). The isolate could be differentiated from its closest phylogenetic neighbours and N. lucentensis NBRC $15854^{\mathrm{T}}$ by its ability to lyse Tween 80 and from its closest phylogenetic neighbours by its ability to grow without $\mathrm{NaCl}$. N. salina, N. kunsanensis and $N$. xinjiangensis have been reported as being halophilic ( $\mathrm{Li}$ et al., 2004; Chun et al., 2000; Li et al., 2003).

Phenotypic, genotypic and chemotaxonomic characteristics show that strain YU1183-22 $2^{\mathrm{T}}$ represents a novel species within the genus Nocardiopsis, for which the name Nocardiopsis nikkonensis sp. nov. is proposed.

\section{Description of Nocardiopsis nikkonensis sp. nov.}

Nocardiopsis nikkonensis (nik.ko.nen'sis. N.L. fem. adj. nikkonensis pertaining to Nikko City, Tochigi, Japan, where the type strain was isolated).

Aerobic, Gram-positive, non-motile actinomycete that produces a white aerial mycelium. Substrate mycelium is pale yellow. Diffusible pigments are not produced. Melanoid pigments are not formed on ISP 6 or ISP 7. Short-branched substrate mycelium fragments into nonmotile elements. Aerial mycelium shows a typical zig-zag formation prior to sporulation. Grows with $0-20 \%(\mathrm{w} / \mathrm{v})$ $\mathrm{NaCl}$, at pH $6-11$ and at 25 and $30{ }^{\circ} \mathrm{C}$, but not at $42{ }^{\circ} \mathrm{C}$. $\mathrm{H}_{2} \mathrm{~S}$ is produced, starch is hydrolysed and Tween 80 is lysed. Nitrate is not reduced. Catalase-positive but oxidasenegative. As sole carbon sources, utilizes L-arabinose, Dfructose, D-galactose, D-glucose, L-rhamnose, sucrose and D-xylose, but not cellobiose, lactose, maltose, D-mannose, melibiose, raffinose, D-ribose, sodium acetate, glycerol, myo-inositol or D-mannitol. Contains meso-diaminopimelic acid but no diagnostic sugars. The predominant menaquinones are MK-10 $\left(\mathrm{H}_{10}\right)$ and MK-10 $\left(\mathrm{H}_{8}\right)$. The polar lipids are phosphatidylcholine and phosphatidylglycerol. The major cellular fatty acids are iso- $\mathrm{C}_{16: 0}$, anteiso$\mathrm{C}_{17: 0}$ and tuberculostearic acid. The DNA G $+\mathrm{C}$ content of the type strain is $72.3 \mathrm{~mol} \%$.

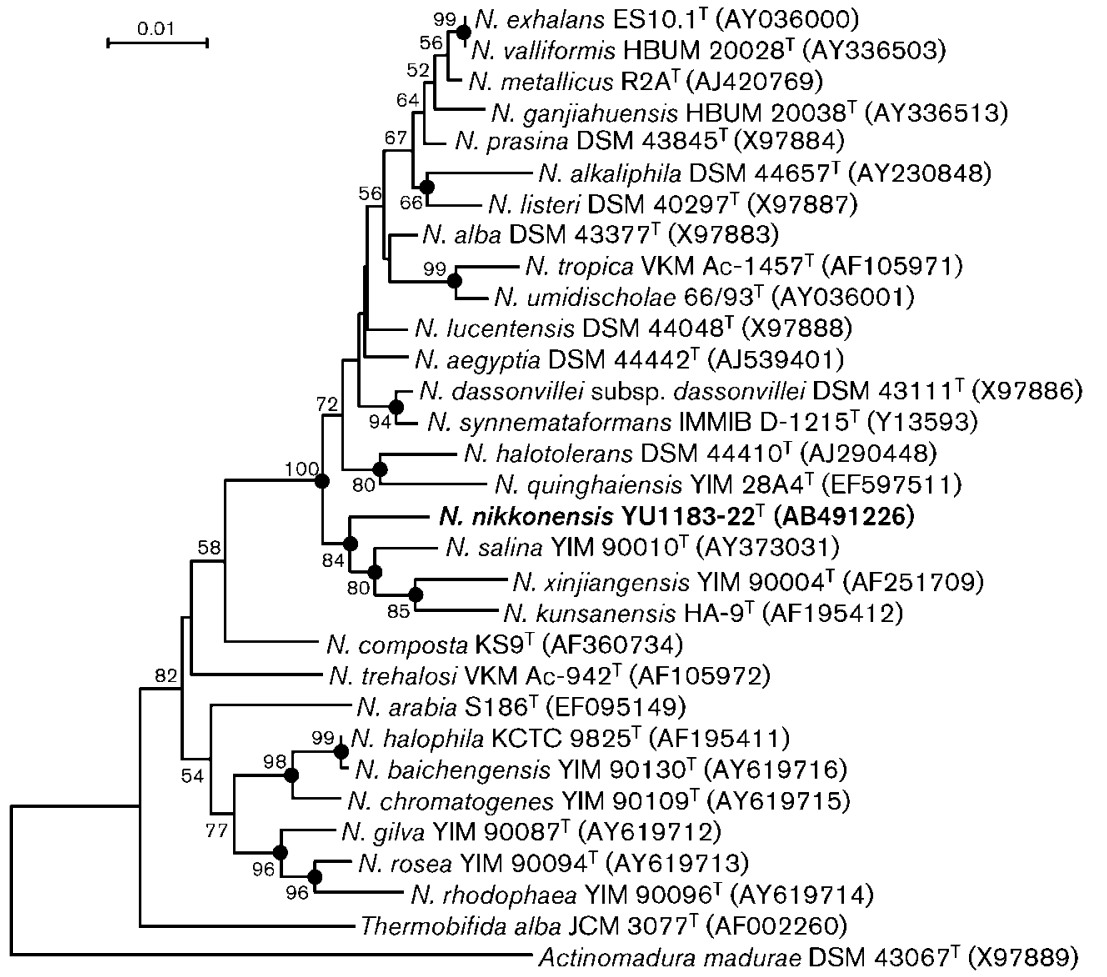

Fig. 1. Phylogenetic tree derived from $16 \mathrm{~S}$ rRNA gene sequences showing the relationship of strain YU1183-22 ${ }^{\top}$ with the type strains of related species of the genus Nocardiopsis. Filled circles indicate that the corresponding nodes are also recovered in trees generated with the minimum-evolution, maximum-parsimony and maximum-likelihood methods. Bootstrap values ( $>50 \%$ ) based on 1000 resamplings are shown at the branch nodes. Bar, 0.01 substitutions per nucleotide position. 
Table 2. Phenotypic characteristics that distinguish strain YU1183- $22^{\top}$ from the type strains of the most closely related species of the genus Nocardiopsis

Strains: 1, Nocardiopsis nikkonensis sp. nov. YU1183-22 ${ }^{\mathrm{T}} ; 2$, N. salina JCM $13364^{\mathrm{T}}$; 3, N. kunsanensis NBRC $100348^{\mathrm{T}}$; 4, N. xinjiangensis NBRC $104162^{\mathrm{T}}$; 5, N. lucentensis NBRC $15854^{\mathrm{T}}$; +, Positive; w, weakly positive; - , negative.

\begin{tabular}{|lccccc|}
\hline Characteristic & $\mathbf{1}$ & $\mathbf{2}$ & $\mathbf{3}$ & $\mathbf{4}$ & $\mathbf{5}$ \\
\hline Growth at/with: & & & & & \\
$10{ }^{\circ} \mathrm{C}$ & $\mathrm{w}$ & - & - & $\mathrm{w}$ & $\mathrm{w}$ \\
$37{ }^{\circ} \mathrm{C}$ & $\mathrm{W}$ & $\mathrm{w}$ & $\mathrm{w}$ & - & + \\
$\mathrm{pH} 11$ & + & $\mathrm{w}$ & + & + & $\mathrm{W}$ \\
$0 \%(\mathrm{w} / \mathrm{v}) \mathrm{NaCl}$ & + & - & - & - & + \\
$20 \%(\mathrm{w} / \mathrm{v}) \mathrm{NaCl}$ & $\mathrm{W}$ & $\mathrm{w}$ & $\mathrm{w}$ & + & - \\
Starch hydrolysis & + & - & + & + & + \\
Nitrate reduction & - & + & - & - & + \\
Tween 80 lipolysis & + & - & - & - & - \\
$\mathrm{H} 2 \mathrm{~S}$ production & + & + & + & - & + \\
Sole carbon sources & & & & & \\
D-Galactose & + & - & + & - & - \\
D-Glucose & + & - & + & - & + \\
Raffinose & - & + & - & - & - \\
D-Ribose & - & + & - & + & - \\
Sucrose & + & + & + & - & + \\
Sodium acetate & - & + & + & - & - \\
\hline
\end{tabular}

${ }^{\star}$ Data for columns 2-4 were taken from Li et al. (2004).

The type strain is YU1183-22 $2^{\mathrm{T}}\left(=\mathrm{NBRC} 102170^{\mathrm{T}}=\mathrm{KCTC}\right.$ $\left.19666^{\mathrm{T}}\right)$, isolated from compost.

\section{Acknowledgements}

We are grateful to Miss Haruna Ashizawa for her excellent technical assistance.

\section{References}

Chen, Y.-G., Cui, X.-L., Kroppenstedt, R. M., Stackebrandt, E., Wen, M.-L., Xu, L.-H. \& Jiang, C.-L. (2008). Nocardiopsis quinghaiensis sp. nov., isolated from saline soil in China. Int J Syst Evol Microbiol 58, 699-705.

Chun, J., Bae, K. S., Moon, E. Y., Jung, S. O., Lee, H. K. \& Kim, S. J. (2000). Nocardiopsis kunsanensis sp. nov., a moderately halophilic actinomycete isolated from a saltern. Int J Syst Evol Microbiol 50, 1909-1913.

Chun, J., Lee, J.-H., Jung, Y., Kim, M., Kim, S., Kim, B. K. \& Lim, Y.-W. (2007). EzTaxon: a web-based tool for the identification of prokaryotes based on $16 \mathrm{~S}$ ribosomal RNA gene sequences. Int J Syst Evol Microbiol 57, 2259-2261.

Evtushenko, L. I., Taran, V. V., Akimov, V. N., Kroppenstedt, R. M., Tiedje, J. M. \& Stackebrandt, E. (2000). Nocardiopsis tropica sp. nov., Nocardiopsis trehalosi sp. nov., nom. rev. and Nocardiopsis dassonvillei subsp. albirubida subsp. nov., comb. nov. Int J Syst Evol Microbiol 50, 73-81.

Felsenstein, J. (1985). Confidence limits on phylogenies: an approach using the bootstrap. Evolution 39, 783-791.
Gerhardt, P. (1981). Manual of Methods for General Bacteriology. Washington, DC: American Society for Microbiology.

Gordon, R. E. \& Mihm, J. M. (1962). Identification of Nocardia caviae (Erikson) nov. comb. Ann N Y Acad Sci 98, 628-636.

Guindon, S., Lethiec, F., Duroux, P. \& Gascuel, O. (2005). PHYML online - a web server for fast maximum likelihood-based phylogenetic inference. Nucleic Acids Res 33 (Web Server Issue), W557-W559.

Hasegawa, T., Takizawa, M. \& Tanida, S. (1983). A rapid analysis for chemical grouping of aerobic actinomycetes. J Gen Appl Microbiol 29, 319-322.

Hatano, K., Nishii, T. \& Kasai, H. (2003). Taxonomic re-evaluation of whorl-forming Streptomyces (formerly Streptoverticillium) species by using phenotype, DNA-DNA hybridization and sequences of $g y r B$, and proposal of Streptomyces luteireticuli (ex Katoh and Arai 1957) corrig., sp. nov., nom. rev. Int J Syst Evol Microbiol 53, 1519-1529.

Hayakawa, M. \& Nonomura, H. (1987). Humic acid-vitamin agar, a new medium for selective isolation of soil actinomycetes. J Ferment Technol 65, 501-509.

Hayakawa, M., lino, S. \& Nonomura, H. (1982). Heavy metal resistance and melanoid pigment production in the streptomycete flora of copper-polluted vineyard soils. Hakkokogaku Kaishi 60, 1-9.

Hozzein, W. N. \& Goodfellow, M. (2008). Nocardiopsis arabia sp. nov., a halotolerant actinomycete isolated from a sand-dune soil. Int J Syst Evol Microbiol 58, 2520-2524.

Isik, K., Chun, J., Hah, Y. C. \& Goodfellow, M. (1999). Nocardia salmonicida nom. rev., a fish pathogen. Int J Syst Bacteriol 49, 833837.

Japan Colour Research Institute (1954). Guide to Colour Standard. Tokyo: Nihon Shikisai Sha Co.

Kämpfer, P., Busse, H. J. \& Rainey, F. A. (2002). Nocardiopsis compostus sp. nov., from the atmosphere of a composting facility. Int $J$ Syst Evol Microbiol 52, 621-627.

Kim, J. W., Adachi, H., Shin-ya, K., Hayakawa, Y. \& Seto, H. (1997). Apoptolidin, a new apoptosis inducer in transformed cells from Nocardiopsis sp. J Antibiot (Tokyo) 50, 628-630.

Küster, E. \& Williams, S. T. (1964). Production of hydrogen sulfide by streptomycetes and methods for its detection. Appl Microbiol 12, 4652.

Kusunoki, S., Ezaki, T., Tamesada, S., Hatanaka, Y., Asano, K., Hashimoto, Y. \& Yabuuchi, E. (1991). Application of calorimetric microdilution plate hybridization for rapid generic identification of 22 Mycobacterium species. J Clin Microbiol 29, 1596-1603.

Lechevalier, M. P. \& Lechevalier, H. A. (1970). Chemical composition as a criterion in the classification of aerobic actinomycetes. Int J Syst Bacteriol 20, 435-443.

Lechevalier, M. P., De Bièvre, C. \& Lechevalier, H. A. (1977). Chemotaxonomy of aerobic actinomycetes: phospholipid composition. Biochem Syst Ecol 5, 249-260.

Li, M.-G., Li, W.-J., Xu, P., Cui, X.-L., Xu, L.-H. \& Jiang, C.-L. (2003). Nocardiopsis xinjiangensis sp. nov., a halophilic actinomycete isolated from a saline sample in China. Int J Syst Evol Microbiol 53, 317-321.

Li, W.-J., Park, D.-J., Tang, S.-K., Wang, D., Lee, J.-C., Xu, L.-H., Kim, C.-J. \& Jiang, C.-L. (2004). Nocardiopsis salina sp. nov., a novel halophilic actinomycete isolated from saline soil in China. Int J Syst Evol Microbiol 54, 1805-1809.

Li, Y. Q., Li, M. G., Li, W., Zhao, J. Y., Ding, Z. G., Cui, X. L. \& Wen, M. L. (2007). Griseusin D, a new pyranonaphthoquinone derivative from a alkaphilic Nocardiopsis sp. J Antibiot (Tokyo) 60, 757-761.

Meyer, J. (1976). Nocardiopsis, a new genus of the order Actinomycetales. Int J Syst Bacteriol 26, 487-493. 
Minnikin, D. E., O'Donnell, A. G., Goodfellow, M., Alderson, G., Athalye, M., Schaal, A. \& Parlett, J. H. (1984). An integrated procedure for the extraction of bacterial isoprenoid quinones and polar lipids. J Microbiol Methods 2, 233-241.

Saito, H. \& Miura, K.-I. (1963). Preparation of transforming deoxyribonucleic acid by phenol treatment. Biochim Biophys Acta 72, 619-629.

Saitou, N. \& Nei, M. (1987). The neighbor-joining method: a new method for reconstructing phylogenetic trees. Mol Biol Evol 4, 406425.

Schaal, K. P. (1985). Identification of clinically significant actinomycetes and related bacteria using chemical techniques. In Chemical Methods in Bacterial Systematics, pp. 359-381. Edited by M. Goodfellow \& D. E. Minnikin. London: Academic Press.

Shirling, E. B. \& Gottlieb, D. (1966). Methods for characterization of Streptomyces species. Int J Syst Bacteriol 16, 313-340.

Sierra, G. (1957). A simple method for the detection of lipolytic activity of micro-organisms and some observations on the influence of the contact between cells and fatty substrates. Antonie van Leeuwenhoek 23, 15-22.

Sun, H. H., White, C. B., Dedinas, J., Cooper, R. \& Sedlock, D. M. (1991). Methylpendolmycin, an indolactam from a Nocardiopsis sp. $J$ Nat Prod 54, 1440-1443.

Takahashi, K. \& Nei, M. (2000). Efficiencies of fast algorithms of phylogenetic inference under the criteria of maximum parsimony, minimum evolution, and maximum likelihood when a large number of sequences are used. Mol Biol Evol 17, 1251-1258.

Tamura, T. \& Hatano, K. (2001). Phylogenetic analysis of the genus Actinoplanes and transfer of Actinoplanes minutisporangius Ruan et al. 1986 and 'Actinoplanes aurantiacus' to Cryptosporangium minutisporangium comb. nov. and Cryptosporangium aurantiacum sp. nov. Int Syst Evol Microbiol 51, 2119-2125.
Tamura, T., Nakagaito, Y., Nishii, T., Hasegawa, T., Stackebrandt, E. \& Yokota, A. (1994). A new genus of the order Actinomycetales, Couchioplanes gen. nov., with descriptions of Couchioplanes caeruleus (Horan and Brodsky 1986) comb. nov. and Couchioplanes caeruleus subsp. azureus subsp. nov. Int J Syst Bacteriol 44, 193-203.

Tamura, K., Dudley, J., Nei, M. \& Kumar, S. (2007). MEGA4: molecular evolutionary genetics analysis (MEGA) software version 4.0. Mol Biol Evol 24, 1596-1599.

Thompson, J. D., Gibson, T. J., Plewniak, F., Jeanmougin, F. \& Higgins, D. G. (1997). The CLUSTAL_X windows interface: flexible strategies for multiple sequence alignment aided by quality analysis tools. Nucleic Acids Res 25, 4876-4882.

Wayne, L. G., Brenner, D. J., Colwell, R. R., Grimont, P. A. D., Kandler, O., Krichevsky, M. I., Moore, L. H., Moore, W. E. C., Murray, R. G. E. \& other authors (1987). International Committee on Systematic Bacteriology. Report of the ad hoc committee on reconciliation of approaches to bacterial systematics. Int J Syst Bacteriol 37, 463-464.

Williams, S. T., Goodfellow, M., Alderson, G., Wellington, E. M. H., Sneath, P. H. A. \& Sackin, M. J. (1983). Numerical classification of Streptomyces and related genera. J Gen Microbiol 129, 1743-1813.

Yang, R., Zhang, L.-P., Guo, L.-G., Shi, N., Lu, Z. \& Zhang, X. (2008). Nocardiopsis valliformis sp. nov., an alkaliphilic actinomycete isolated from alkali lake soil in China. Int J Syst Evol Microbiol 58, 1542-1546.

Yassin, A. F., Rainey, F. A., Burghardt, J., Gierth, D., Ungerechts, J., Lux, I., Seifert, P., Bal, C. \& Schaal, K. P. (1997). Description of Nocardiopsis synnemataformans sp. nov., elevation of Nocardiopsis alba subsp. prasina to Nocardiopsis prasina comb. nov., and designation of Nocardiopsis antarctica and Nocardiopsis alborubida as later subjective synonyms of Nocardiopsis dassonvillei. Int J Syst Bacteriol 47, 983-988.

Zhang, X., Zhang, L.-P., Yang, R., Shi, N., Lu, Z., Chen, W. X., Jiang, C.-L. $\& \mathbf{X u}$, L.-H. (2008). Nocardiopsis ganjiahuensis sp. nov., isolated from a soil from Ganjiahu, China. Int J Syst Evol Microbiol 58, 195-199. 